\title{
Transcriptome analysis of MENX-associated rat pituitary adenomas identifies novel molecular mechanisms involved in the pathogenesis of human pituitary gonadotroph adenomas
}

\author{
Misu Lee · Ilaria Marinoni • Martin Irmler • Tsambika Psaras • Jürgen B. Honegger • \\ Rudi Beschorner • Natasa Anastasov • Johannes Beckers • Marily Theodoropoulou • \\ Federico Roncaroli $\cdot$ Natalia S. Pellegata
}

Received: 25 March 2013 / Revised: 15 May 2013 / Accepted: 18 May 2013 / Published online: 12 June 2013

(C) The Author(s) 2013. This article is published with open access at Springerlink.com

\begin{abstract}
Gonadotroph adenomas comprise 15-40 \% of all pituitary tumors, are usually non-functioning and are often large and invasive at presentation. Surgery is the first-choice treatment, but complete resection is not always achieved, leading to high recurrence rates. As gonadotroph adenomas poorly respond to conventional pharmacological therapies, novel treatment strategies are needed. Their identification has been hampered by our incomplete understanding of the molecular pathogenesis of these tumors. Recently, we demonstrated that MENX-affected rats develop gonadotroph adenomas closely resembling their human counterparts. To discover new genes/pathways involved in gonadotroph cells
\end{abstract}

M. Lee and I. Marinoni contributed equally to the paper.

Electronic supplementary material The online version of this article (doi:10.1007/s00401-013-1132-7) contains supplementary material, which is available to authorized users.

M. Lee $\cdot$ I. Marinoni $\cdot$ N. S. Pellegata $(\bowtie)$

Institute of Pathology, Helmholtz Zentrum München,

Neuherberg, Germany

e-mail: natalia.pellegata@helmholtz-muenchen.de

Present Address:

I. Marinoni

Institute of Pathology, University of Bern, Bern, Switzerland

M. Irmler $\cdot$ J. Beckers

Institute of Experimental Genetics, Helmholtz Zentrum

München, Neuherberg, Germany

T. Psaras · J. B. Honegger

Department of Neurosurgery, University of Tübingen,

Tübingen, Germany

R. Beschorner

Department for Neuropathology, Institute for Pathology and

Neuropathology, University of Tübingen, Tübingen, Germany tumorigenesis, we performed transcriptome profiling of rat tumors versus normal pituitary. Adenomas showed overrepresentation of genes involved in cell cycle, development, cell differentiation/proliferation, and lipid metabolism. Bioinformatic analysis identified downstream targets of the transcription factor SF-1 as being up-regulated in rat (and human) adenomas. Meta-analyses demonstrated remarkable similarities between gonadotroph adenomas in rats and humans, and highlighted common dysregulated genes, several of which were not previously implicated in pituitary tumorigenesis. Two such genes, CYP11A1 and NUSAP1, were analyzed in 39 human gonadotroph adenomas by qRT-PCR and found to be up-regulated in 77 and $95 \%$ of cases, respectively. Immunohistochemistry detected high P450scc (encoded by CYP11A1) and NuSAP expression in 18 human gonadotroph tumors. In vitro studies demonstrated for the first time that Cypllal is a target of SF-1 in gonadotroph cells and

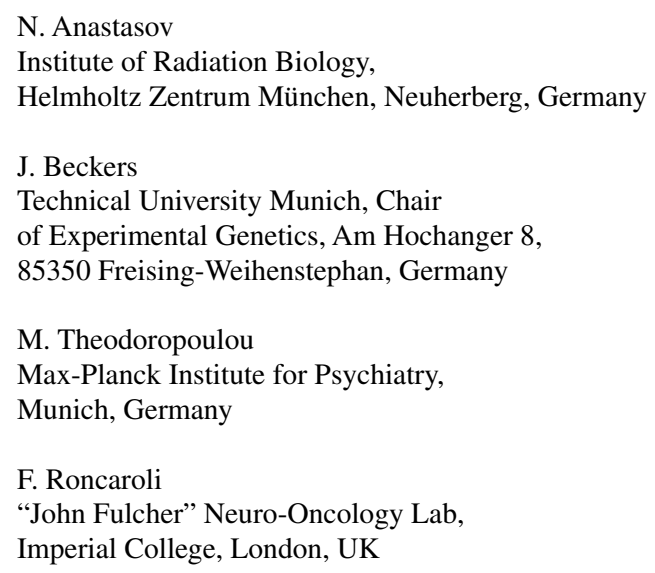


promotes proliferation/survival of rat pituitary adenoma primary cells and cell lines. Our studies reveal clues about the molecular mechanisms driving rat and human gonadotroph adenomas development, and may help identify previously unexplored biomarkers for clinical use.

Keywords Pituitary gonadotroph adenoma . Transcriptome analysis · MENX model · CYP11A1 · NUSAP1

\section{Introduction}

Clinically non-functioning adenomas of the pituitary gland account for about $30 \%$ of all adenomas. About $80 \%$ of them belong to the gonadotroph lineage. They are usually diagnosed when signs and symptoms of mass effects occur, and about $40 \%$ of them extend to the cavernous sinus and, less commonly, invade the sellar floor, making their resection and post-operative radiotherapy challenging [14, 34]. In addition, they are usually resistant to pharmacological treatment with somatostatin analogs and dopamine agonists. Chemotherapy has been reserved as salvage therapy in aggressive cases although the results have often been disappointing [34]. Novel therapeutic approaches are therefore needed for these tumors.

A prerequisite to identify novel therapeutic targets for human tumors is a good understanding of the pathogenetic mechanisms. The molecular mechanisms underlying the development of PAs in general, and of gonadotroph adenomas in particular, have only been incompletely unraveled and this is in part due to the limited availability of suitable animal models and by the fact that those available are not always representative of human adenomas [27].

We have recently identified a multiple endocrine neoplasia syndrome occurring in a Sprague-Dawley-derived rat strain (named MENX) characterized by the occurrence of spontaneous PAs with complete penetrance. MENX is caused by a biallelic loss-of-function mutation in $C d k n 1 b$, encoding the cell cycle inhibitor p27, which results in a highly unstable protein [29, 33]. MENX-associated PAs are histologically and ultrastructurally remarkably similar to human gonadotroph adenomas. They also show high mitotic activity and elevated Ki67 labeling index [26]. Primary cells derived from these tumors are a suitable model for pharmacological studies of PAs [24].

To elucidate the mechanisms associated with the development of human gonadotroph adenomas we exploited the MENX model and performed whole genome transcriptome analysis of the rat tumors and of normal pituitary tissues of wild-type animals. With this approach, we have identified genes differentially expressed in rat PAs that had been previously found dysregulated in human adenomas by array analysis, but not yet further validated. We here show that two such genes (i.e. CYPIIAl and NUSAP1) are highly expressed at both mRNA and protein level in human gonadotropinomas and may represent novel biomarkers of these tumors. In vitro functional assays demonstrated for the first time that the high expression of Cypllal promotes proliferation/survival of PA cells (gonadotroph- and somatotroph-derived), thereby supporting a role for this gene in pituitary tumorigenesis. We also determined that Cypllal expression is regulated by the steroidogenic transcription factor SF-1 in gonadotroph cells. Noteworthy, in addition to NUSAP1, other genes involved in mitosis were found overexpressed in both rat and human PAs by meta-analysis. If further validated, these genes may represent novel potential targets for the therapy of gonadotropinomas.

\section{Materials and methods}

\section{Human pituitary tissue samples}

Pituitary adenoma samples were obtained from patients at Imperial College and the University of Tübingen at the time of transsphenoidal surgery. All patients consented for research and appropriate ethical approval for the study was obtained. Fragments of the specimens that were not used for diagnostic assessment were snap-frozen at $-80{ }^{\circ} \mathrm{C}$. Gonadotroph tumors were defined as demonstrating positive immunostaining for $\mathrm{LH} \beta, \mathrm{FSH} \beta$ or $\alpha \mathrm{GSU}$ in $>5-10 \%$ of cells. Extension to the cavernous sinus and invasiveness of the sellar floor were identified at preoperative magnetic resonance imaging (MRI). The modified Hardy criteria were applied [18]. Post-mortem samples of normal adenohypophysis used for immunohistochemistry (IHC) were obtained from Imperial College. Autopsies were performed within $2-18 \mathrm{~h}$ from death and were formalin-fixed and routinely processed to paraffin embedding. Consent for research use of this tissue was obtained from families. RNA of normal pituitary tissues was purchased from BioChain Inc (Hayward, CA, USA).

\section{Rat pituitary tissue samples}

MENX-affected rats develop multifocal pituitary adenomas in the anterior lobe of the gland. Based on hormone expression by immunohistochemistry we could establish that these tumors mainly derive from gonadotroph cells [26]. The lesions become histologically detectable at 4 months of age and progress to become large, mature tumors that efface the gland at 7-8 months. The number of cells expressing $\mathrm{LH} \beta$ or FSH $\beta$ decreases with tumor progression and is negligible in the largest adenomas, while tumors remain positive for the common gonadotropin alpha subunit ( $\alpha \mathrm{GSU})$. 
Rat adenomas show mitotic activity and high Ki67 labeling (average $8 \%$ at 7-8 months), thus resembling aggressive pituitary adenomas. Approximately $10-17 \%$ of the pituitary lesions contain cells expressing growth hormone $(\mathrm{GH})$ or prolactin (PRL) [26]. The pituitary glands used for RNA extraction (upon microdissection) derived from rats aged $7-8$ months having large tumors approximately $1-2 \mathrm{~mm}$ in size.

\section{RNA isolation and microarray preparation}

Rat RNA was extracted from macrodissected pituitary tissues and processed for array analysis as reported [30]. Amplified cDNA ( $2 \mu \mathrm{g}$ ) was hybridized on Affymetrix Rat Gene 1.0 ST arrays (Santa Clara, CA, USA) containing about $26 \mathrm{k}$ gene-level probe sets. Staining and scanning was done according to the Affymetrix expression protocol. RNA was extracted from frozen human pituitary tumor samples following standard protocols [30].

\section{Biostatistical and bioinformatic analysis}

Expression console (Affymetrix) was used for quality control and to obtain annotated normalized RMA gene-level data (standard settings including median polish and sketchquantile normalization). Statistical analyses and heat maps were generated in CARMAweb [36]. Genewise testing for differential expression was done employing $t$ test and Benjamini-Hochberg multiple testing correction (FDR $<5 \%$ ). Genes with fold-changes $>2 \times$ were further analyzed using GePS software (Genomatix Software GmbH, Munich, Germany). Signaling pathways containing, or regulated by, differentially expressed genes were identified using the Ingenuity Pathway Analysis (IPA) library of canonical pathways. Array data were submitted to Gene Expression Omnibus (GSE23207). The comparison of rat and human datasets was done in Venny (http://bioinfogp.cnb.csic.es/ tools/venny/index.html) based on the match of human genes to rat probe set IDs via rat Entrez IDs provided by Affymetrix. Human Entrez IDs of regulated genes were matched to rat Entrez IDs mainly based on the NCBI homologene database, supplemented with information provided by Ingenuity pathway software. Human datasets were taken from publications: Morris et al. [32], 1,723 probe sets with fold-changes $>1.5 \times$; Moreno et al. [31], Supplementary Table 2,297 probe sets with fold-changes $>2 \times$ ) or calculated from.cel files; Michaelis et al. [28], Acc. Number GSE26966, analysis as described above, 3,558 probe sets with ratios $>2 \times$. All human datasets were done with Affymetrix arrays and human Entrez IDs of regulated probe sets were taken from annotations provided by Affymetrix. For pairwise comparisons of rat and human datasets, probe set based gene lists from the Venn diagram were further processed: for redundant entries only the entry with the highest ratio in rat was kept, and datasets were filtered for the same direction of regulation in rat and human datasets.

Cell culture, treatments and assays

GH3 and Y1 cells were purchased from the ATCC and grown in DMEM supplemented with $10 \%$ (v/v) FBS and $1 \%(\mathrm{v} / \mathrm{v})$ penicillin-streptomycin. The murine gonadotroph cell line L $\beta$ T2 was kindly provided by P. Mellon (University of California, San Diego, USA) and was grown in DMEM + GlutaMAX ${ }^{\text {TM}}$-I plus $4.5 \mathrm{~g} / 1$ D-glucose and pyruvate with $10 \%(\mathrm{v} / \mathrm{v})$ FBS and $1 \%(\mathrm{v} / \mathrm{v})$ penicillin-streptomycin. Primary pituitary tumor cells were isolated from mutant rat pituitaries and grown as previously described [24]. Media, serum and supplements were from Gibco/Invitrogen (Karlsruhe, Germany). Transfection with siRNA oligos was performed as previously reported [24]. For infections, GH3 and primary tumor cells were plated on 96-well plates and $24 \mathrm{~h}$ later cells were infected by lentiviral vectors expressing the green fluorescence protein (GFP) or GFP and shRNA against Cypllal. Virus production and lentiviral infection were performed according to previous protocols [2]. WST-1 colorimetric assay (Roche, Mannheim, Germany) for cell viability was performed $72 \mathrm{~h}$ after infection according to the manufacturer's recommendations.

Apoptosis was measured by assessing the activity of caspase-3/7 using Caspase-Glo ${ }^{\circledR}$ 3/7 Assay kit (Promega, Mannheim, Germany). Primary cells or transfected GH3 cells were plated in 96-well plates and $36 \mathrm{~h}$ later were infected with sh-Cypllal or mock GFP lentiviral vectors. Fortyeight $h$ after treatment, caspase-3/7 enzymatic activity was assessed with a proluminescent caspase-3/7 substrate which contains the tetrapeptide sequence DEVD. Luminescence was measured using a luminometer (Berthold, Bad Wildbad, Germany).

For treatment with ethyl 2-[[2-[2-[(2,3-dihydro-1,4-benzodioxin-6-yl)amino]-2-oxoethyl]-1,2-dihydro-1-oxo5-isoquinolinyl] (IsoQ) (Tocris Bioscience, Bristol, UK), $2.5 \times 10^{4}$ primary rat pituitary cells $\left(2.5 \times 10^{4}\right.$ cells/well $)$ or LBT2 cells $\left(1 \times 10^{4}\right.$ cells/well $)$ were seeded into 96-well plates and allowed to settle for $36 \mathrm{~h}$. IsoQ was dissolved in DMSO and serial dilutions (10 $\mu \mathrm{M}-10 \mathrm{nM})$ were prepared in culture medium. Treated cells were incubated with IsoQ for 24 and $48 \mathrm{~h}$, while control cells with $0.01 \%(\mathrm{v} / \mathrm{v})$ DMSO. Cell viability was assessed using the WST-1 assay as above.

\section{Quantitative TaqMan RT-PCR}

Quantititative RT-PCR was performed using TaqMan inventoried primers and probes for the genes reported in 
the article and for the rat beta 2-microglobulin gene, mouse beta 2-microglobulin gene or human TBP gene as internal controls (Applied Biosystem, CA, USA). RNA was extracted and TaqMan assays were set up as previously reported [30].

\section{RNA interference}

The specific Cypllal shRNA sequence was cloned into the pSUPER lentiviral vector. The sequence of the complementary oligonucleotides is: sh-Cypllal Fw GATCC GGATGTTGGAGGAGATCGTTTCAAGAGA AC GATCTCCTCCA ACATCCTTTTTG; Rev: AATTCAAA AAGGATGTTGGAGGAGATCGTTCTCTT GAAACGA TCTCCTCCAACATCCG.

Immunohistochemistry and Immunofluorescence

Immunohistochemistry (IHC) staining was performed on an automated immunostainer (Ventana Medical Systems, Tucson, AZ, USA) according to the manufacturer's protocols with minor modifications, as previously described [30]. Primary antibodies were raised against Ass1 (Sigma, Louis, MO, USA); Ki-67 (Clone B56, Dako, Hamburg, Germany); rat P450scc (Abcam, Abcam, Cambridge, UK); human P450scc (Santacruz, Heidelberg, Germany); NuSAP (Proteintech, Chicago, IL, USA). Antibodies were diluted in Dako REALTM antibody diluent (Dako). The supersensitive detection system (BioGenex, Munich, Germany) was used and the immunoreaction was developed in the diamino-benzidine (DAB) supplied with the kit (Vector lab, Burlingame, CA). Positive controls were included in each batch. To score the P450scc staining, both the intensity of the staining and the number of positive tumor cells were taken into consideration. For number of positive cells, we used a score: $0=0 \%$ (or $<1 \%$ ) positive cells; $1=$ up to $25 \%$ positive cells; $2=$ up to $50 \% ; 3=$ up to $75 \%$; $4=$ up to $100 \%$. For staining intensity, a 4 -scaled scoring system was used: $0=$ negative, $1=$ weak, $2=$ moderate, $3=$ strong. These values were then multiplied to obtain 'immunoreactivity scores' (IRS). Ki67 and NuSAP nuclear immunoreactivity was determined semiquantitatively and was indicated as the percent of positive cells against all neoplastic cells in the section examined (Labeling Index, LI). Images were recorded using a Hitachi camera HW/ C20 installed in a Zeiss Axioplan microscope with Intellicam software (Carl Zeiss MicroImaging $\mathrm{GmbH}$, Gottingen, Germany).

For immunofluorescence (IF), we used the primary antibodies used for IHC and secondary anti-mouse Alexa Fluor $^{\circledR} 555$ Conjugate (Cell Signaling) or anti-rabbit FITCconjugated (Invitrogen, Darmstadt, Germany) antibodies as reported [26]. Sections were then analyzed with a
Zeiss Axiovert 200 epifluorescence microscope including Apotome unit (Carl Zeiss MicroImaging GmbH).

Statistical analysis

Results of the cell viability assays are shown as the mean of values obtained in independent experiments \pm SEM (standard error of the mean). A paired two-tailed Student's $t$ test was used to detect significance between two series of data and $P$ value $(P)<0.05$ was considered statistically significant.

\section{Results}

Genetic signature of MENX-associated pituitary adenomas

In order to unravel the genetic changes associated with pituitary adenoma (PA) formation, we performed whole genome transcriptome analysis of 16 individual pituitary lesions from 11 adult MENX mutant rats (8 months of age) and compared them with 5 normal pituitaries. Using a >twofold-change cut-off for gene expression changes, 487 probe sets appeared up-regulated in adenomas versus normal wild-type gland, and 400 were down-regulated (Supplementary Fig. 1 and Dataset 1). The relative high number of differentially expressed transcripts is not unexpected since normal pituitary is composed of multiple cell types of which only 10-20\% are gonadotroph cells. Gene ontology (GO) term enrichment analysis showed that genes related to cell cycle $(P=9.85 \mathrm{E}-09)$, development $(P=1.2 \mathrm{E}-06)$, cell differentiation $(P=1.36 \mathrm{E}-06)$, cell proliferation $(P=2.53 \mathrm{E}-07)$, and lipid metabolism $(P=9.43 \mathrm{E}-04)$ are overrepresented in our dataset (ratios $>$ twofold, Table 1). Genes encoding proteins involved in cell cycle regulation and especially in mitosis such as Aurka, Bub1, Bublb, Ccnal, Ccnb1, Ccnb2, Ccne1, Cdc2, Cdc20, Cdkn3, Kif4, Kif11, Nusap1, Prcl, as well as genes involved in pituitary development or adenohypophyseal cell differentiation, such as Dax-1/NrObl, Egrl, Fgfr2, Neurod1, Notch2, Nr5a1, Poulf1, Tbx19 [6, 10, 23] were differentially expressed in rat PAs (Table 1). Array data mining found that genes such as Ccnbl, Igfbp3, Nusapl, Pttg1, Racgap1, Top2a, Tpx2, which are associated with the aggressive behaviour of various human tumors, including PAs, and proto-oncogenes such as Ect2, Kit, Kras, Lyn, Ret are up-regulated in rat adenomas [12, 15, 42, 43]. This result is in agreement with the elevated proliferative activity of the tumors [26]. Interestingly, also genes belonging to the category "lipid metabolic process" were significantly overrepresented in the rat adenomas, and several of them are known targets of the transcription factor steroidogenic factor 1 (SF-1) (see below). 
Table 1 Enriched GO categories by GePS software from Genomatix

\begin{tabular}{|c|c|c|c|c|c|}
\hline GO-term & GO-term ID & $P$ value & $\begin{array}{l}\text { Observed/ } \\
\text { expected }\end{array}$ & $\begin{array}{l}\text { Number of } \\
\text { genes in GO }\end{array}$ & Selected dysregulated genes \\
\hline \multicolumn{6}{|c|}{ Enriched terms within the up-regulated genes } \\
\hline Cell cycle & GO: 0007049 & $9.85 \mathrm{E}-09$ & $42 / 16$ & 667 & $\begin{array}{l}\text { Aurka, Bmp7, Bub1, Bublb, Ccnbl, Ccnb2, Cdc2, } \\
\text { Cdc20, Cdknla, Cdkn2c, Cdkn3, Cenpf, Cited2, Id2, } \\
\text { Nusapl, Pttgl }\end{array}$ \\
\hline $\begin{array}{l}\text { Developmental } \\
\text { process }\end{array}$ & GO: 0032502 & $1.20 \mathrm{E}-06$ & $98 / 62$ & 2,597 & $\begin{array}{l}\text { Angpt2, Ass1, Bmp7, Cdkn2c, Cited2, Cyp11a1, } \\
\text { Fgfr2, Id2, Igfbp3, Igfbp7, Lyn, Neurod1, Nos1, } \\
\text { Nr0b2, Nr0b1, Nr5a1, Ret, Sox11 }\end{array}$ \\
\hline Cell differentiation & GO: 0030154 & $1.36 \mathrm{E}-06$ & $63 / 34$ & 1,431 & $\begin{array}{l}\text { Angpt2, Apoe, Ar, Bag1, Bmp7, Ccnb1, Cdc2, Cdkn2c, } \\
\text { Cenpf, Cited2, Cyp11a1, Fgfr2, Id2, Igfbp3, Kit, } \\
\text { Kras, Lyn, Neurod1, Neurod4, Nr0b1, Nr5a1, } \\
\text { Racgap1, Ret, Sox11, Top2a, Tshr, Vegfa }\end{array}$ \\
\hline Cell proliferation & GO: 0008283 & $2.53 \mathrm{E}-07$ & $45 / 20$ & 832 & $\begin{array}{l}\text { Apoe, Ar, Bub1, Ccna2, Ccnb1, Cdc2, Cdc20, Cdkn1a, } \\
\text { Cdkn1c, Cdkn2c, Cenpf, Fgfr2, Gnrhr, Id2, Igfbp3, } \\
\text { Kit, Kras, Lyn, Pttg1, Racgap1, Scarb1, Sox11, Tac1, } \\
\text { Vegfa }\end{array}$ \\
\hline $\begin{array}{l}\text { Lipid metabolic } \\
\text { process }\end{array}$ & GO: 0006629 & $9.43 \mathrm{E}-04$ & $33 / 19$ & 772 & $\begin{array}{l}\text { Apoe, Apof, Cyp1b1, Cyp11a1, Cyp11b1, Cyp11b2, } \\
\text { Fdxr, Nr0b1, Scarbl }\end{array}$ \\
\hline \multicolumn{6}{|c|}{ Enriched terms within the down-regulated genes } \\
\hline $\begin{array}{l}\text { Developmental } \\
\text { process }\end{array}$ & GO: 0032502 & $7.73 \mathrm{E}-10$ & $69 / 34$ & 2,597 & $\begin{array}{l}\text { Egr1, Notch2, Nr4a3, Sema3e, Dlk1, Angptl, Nr4a2, } \\
\text { Ghrhr, Adcyap1r1, Pou1f1, Tbx19 }\end{array}$ \\
\hline $\begin{array}{l}\text { Negative } \\
\text { regulation of } \\
\text { cell proliferation }\end{array}$ & GO: 0008285 & $9.29 \mathrm{E}-03$ & $9 / 4$ & 271 & $\begin{array}{l}\text { Nfib, Notch2, Gjb6, Wfdd, Rbp4, Gpc3, Cdk6, Msx1, } \\
\text { Slit2 }\end{array}$ \\
\hline
\end{tabular}

Genes encoding pituitary hormones were down-regulated in rat adenomas, with the exception of Cga encoding the common alpha subunit of the gonadotropins ( $\alpha \mathrm{GSU})$, which was highly expressed in all adenomas (Supplementary Fig. 1). These results are in keeping with previous immunohistochemical stainings showing that the large, older rat pituitary lesions do not express any hormone subunit except $\alpha \mathrm{GSU}$ [26].

Transcription factor analysis using Ingenuity Pathway Analysis (IPA) predicted the activation of several upstream transcription factors, including $\mathrm{Nr} 5 \mathrm{al}$ ( $z$-score $=+2.34$; $P=5 \mathrm{E}-08$ ) encoding SF-1 (Supplementary Table 1). The genes encoding the gonadotropin hormone subunits $\mathrm{LH} \beta$ and $\mathrm{FSH} \beta$, which are transcriptionally regulated by SF-1 in gonadotroph cells, are down-regulated in the large rat tumors, as mentioned above. In contrast, several downstream targets of SF-1 were found highly expressed in the adenomas. While the mRNA level Nr5al was up-regulated 2.7-fold in the adenomas (Dataset 1), its downstream targets were overexpressed up to 23-fold in the tumors, including Angpt2, Cyp11a1, Cyp11b1, Cyp11b2, Giot1, Gnrhr, Nos1, NrOb1/Dax1, NrOb2, Scarb1. Also Fgf13 and Coll8al were up-regulated, as reported in adrenal cancer cells [8], and so was Cited2, encoding for a co-activator of SF-1 during adrenal development [40]. Altogether, these data suggest that the activity of SF-1 is enhanced in rat PAs (Supplementary Fig. 2a). Further support to the activation of SF-1 in the rat tumors came from the validation of Cypl1b1 and Cyp11b2 overexpression in independent adenoma samples (Supplementary Fig. 2b). Several of the SF-1 targets mentioned above play a physiological role in the synthesis or transport of steroid hormones in steroidogenic tissues and have not so far been implicated in adenohypophyseal tumorigenesis.

Real-time quantitative RT-PCR (qRT-PCR) for 9 selected overexpressed genes was performed on 11 additional individual pituitary adenomas to validate the array data (Fig. 1a). These tumors were compared with five pituitaries from wild-type rats. $\mathrm{Nr} 5 \mathrm{al}$ (Sf-1) and $\mathrm{Cga}(\alpha \mathrm{GSU})$ were included as controls because the encoded proteins are expressed in these tumors [26], while the other transcripts were chosen because they have interesting functions and they span a broad range of increased fold-changes, from $\sim 3$-fold to $>20$-fold. The results confirmed the up-regulation of these genes in rat PAs, with Cdknlc (p57) showing a trend toward higher levels in the tumors versus normal pituitary which did not reach the statistical significance (Fig. 1a). qRT-PCR also confirmed the down-regulation of Pomc, Lhb, Fshb in rat adenomas (Fig. 1b).

The differential expression of selected genes was further validated with immunohistochemistry (IHC) and immunofluorescence (IF). Stainings for argininosuccinate synthetase 1 (Ass1), NuSAP, Cyclin E, P450scc (encoded by Cypllal) showed higher Ass1 and P450scc levels in 


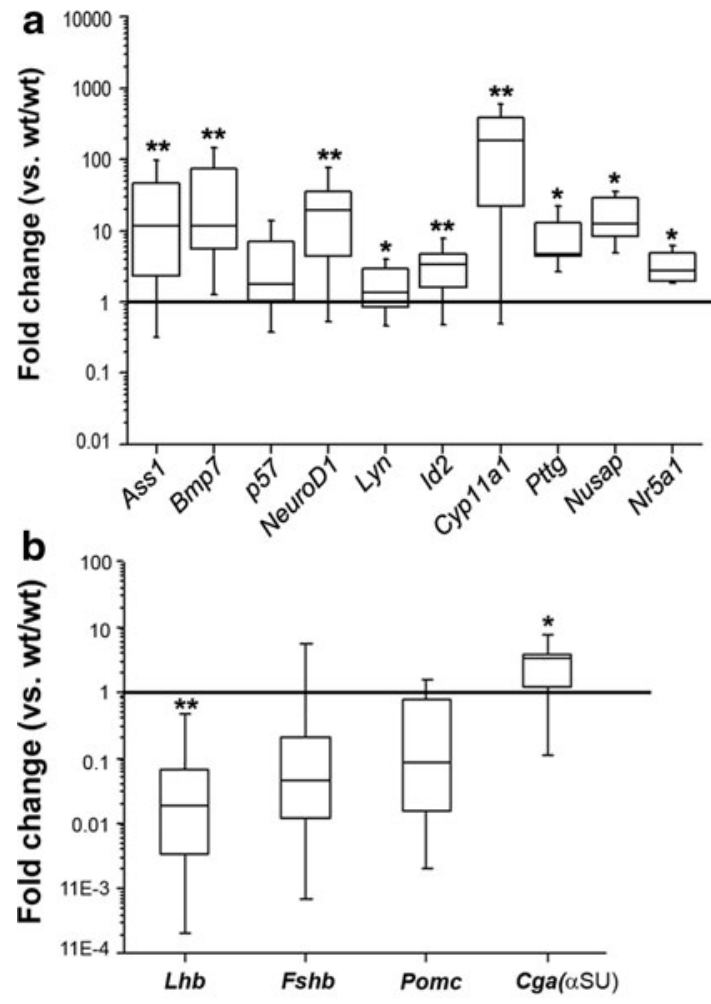

Fig. 1 Validation of selected genes by qRT-PCR and by IHC on rat PA tissues. a, b RNA was extracted from 11 macrodissected pituitary tumors of adult mutant rats and from five normal pituitaries of wildtype (wt/wt) rats. qRT-PCR was performed using TaqMan primer and probe sets specific to a rat genes up-regulated by array analysis: Ass1, Bmp7, p57, NeuroD1, Lyn, Id2, Cpy11a1, Pttg, Nusap, Nr5a1 and b rat genes down-regulated by array analysis: $\operatorname{Lh} \beta, F \operatorname{sh} \beta, P o m c, C g a$ $(\alpha \mathrm{GSU})$. The relative mRNA expression level of the target genes was normalized for input RNA using the housekeeping $\beta 2$-microglobulin gene and a calibrator RNA always run in parallel and was calculated with the $2^{-\Delta \Delta \mathrm{Ct}}$ formula. The obtained relative value was normalized against the average level in normal pituitary, arbitrarily set to 1 . The

tumors compared with non-tumorous pituitary tissue of mutant rats or wild-type rat pituitaries (Fig. 1c). Similarly, NuSAP- and CyclinE-positive cells were found in higher number in adenomas compared with surrounding nontumorous gland, or with normal pituitaries (Fig. 1c).

Dysregulated pathways and genes previously associated with human pituitary tumors

Some of the pathways identified as dysregulated in rat PAs by the IPA software have also been implicated in human PAs by proteomics profiling, and include cell cycle, lipid metabolism and endocrine system development [45]. In addition, the homologues of several genes up-regulated in the rat tumors had also been already implicated in human non-functioning/gonadotroph PAs. Examples are ECT2, NEUROD1, PTTG1,VEGFA and the oncogene c-fos [22,

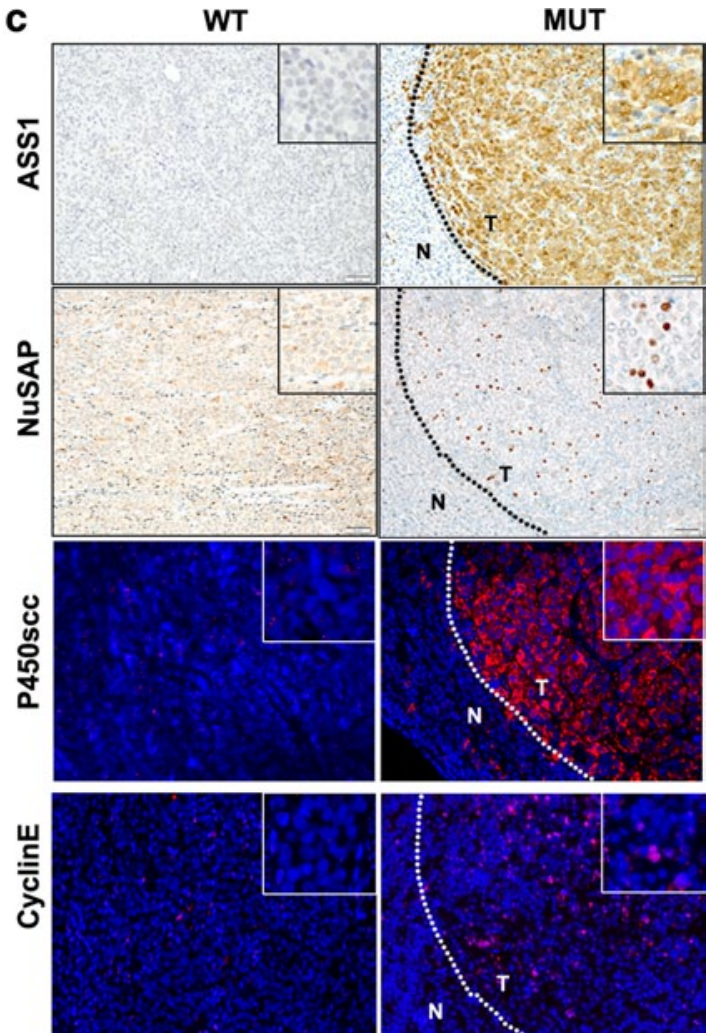

boundary of the box closest to zero indicates the 25th percentile, the line within the box marks the median, and the boundary of the box farthest from zero indicates the 75th percentile. Error bars above and below the box indicate the 99th and 1th percentiles. $* P<0.05$, $* * P<0.001$. c Formalin-fixed, paraffin-embedded (FFPE) pituitaries from adult wild-type (WT) (left) and mutant (MUT) (right) rats were used. IHC was performed using antibodies against ASS1 and NuSAP and counterstained with hematoxylin. Immunofluorescence was performed with antibodies against P450scc or Cyclin E and nuclei were counterstained with DAPI. $T$ tumor area, $N$ normal adjacent area. Original magnification: $\times 200$; insets: $\times 400$

$25,31,32]$. NOS1 and DAX1, regulated by and/or regulating the transcription factor SF-1, are highly expressed in human gonadotroph adenomas [20,39]. Androgen receptor (AR) is expressed in $74 \%$ of gonadotropinomas [37], and $D L K 1$ is silenced in non-functioning adenomas, while it is highly expressed in functional adenomas [1].

Studies comparing the transcriptome of human gonadotroph adenomas with that of normal pituitary tissues $[1,9$, $11,28,31]$ or of non-invasive versus invasive gonadotroph adenomas $[12,19]$ have been performed. We therefore compared our Dataset 1 with the available lists of significantly differentially expressed genes in human non-functioning/ gonadotroph adenomas. Examples of concordantly dysregulated genes in both species are reported in Supplementary Table 2. Remarkably, the degree of overlap of genes differentially expressed among different human sample sets is similar to the overlap between rat and human datasets, as 


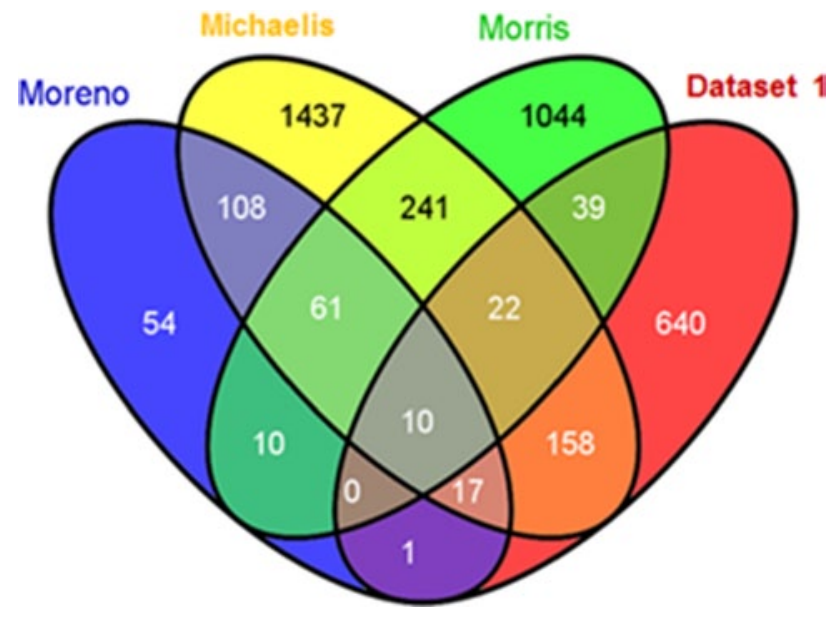

Fig. 2 Overlap of differentially expressed genes. Venn diagram displaying the overlap among lists of differentially expressed genes from gene expression studies in human gonadotroph/non-functioning PAs $[28,31,32]$ and rat PAs (Dataset 1). For details, see "Materials and methods"

estimated using Venn diagrams (Fig. 2). The 10 genes differentially expressed in all the datasets we compared are: Ptprk, Atp8a1, Lgals3, Nr4a2, Pon3, Fos, Angpt1, Amigo2, Rcan2, Maob (for details, please refer to "Materials and methods"). We found several common dysregulated genes in the rat tumors and in the dataset recently published by Michaelis et al. [28] analyzing 14 human gonadotroph adenomas. Among the genes dysregulated in both rat and human adenomas, we found genes associated with pituitary function or pituitary tumorigenesis and mentioned earlier in the article, such as $A R, C C N B 1, D L K 1, E C T 2, F O S, N E U$ $R O D 1, N R O B 1 / D A X 1, V E G F$. Genes encoding transcription factors and hormones important in other pituitary cell lineages (i.e. POU1F1/PIT-1, TBX19, GH, PRL, POMC) are down-regulated in rat and human gonadotroph-derived adenomas, as expected. BAGl, coding for an anti-apoptotic protein, was found overexpressed in human non-functioning PAs by array analysis [32], and is also up-regulated in MENX-associated adenomas. Similarly to the rat tumors, several downstream targets of SF-1 were found to be highly expressed in human gonadotroph adenomas by array analysis (Supplementary Fig. 3). Interestingly, several genes dysregulated in both human and rat array datasets, although not yet evaluated in PAs, have been shown to play a role in other human malignancies, such as BUB1, BUB1B, GALNT12, GPC3, HMMR, KIF4, NR4A3, NUSAP1, PDE4B, PRC1 and thus warrant follow-up studies.

CYP11A1 and NUSAP1 are overexpressed in human PAs

Among the genes overexpressed in the rat pituitary adenomas, predicted to be up-regulated in at least 2 of the 3 human expression array studies by data mining (Supplementary Table 2, in bold), and never before associated with pituitary adenomas, are Cypllal and Nusapl. Thus, these two genes were selected for further analyses. Cypllal encodes P450scc, the mitochondrial enzyme that catalyzes the conversion of cholesterol to pregnenolone in steroidogenic tissues. Nusapl encodes a protein that plays a role in spindle microtubule organization and is necessary for cell division [35]. To verify whether these genes are truly upregulated in human gonadotroph adenomas, we performed qRT-PCR in a series of 39 samples. NR5AI and NEURODI were also included in the analysis as they are expected to be up-regulated in these tumors. We found that CYP11A1 was up-regulated in $77 \%$ (27 out of 35) and NUSAP1 in $95 \%$ (37 out of 39) of the human PAs (Fig. 3a). NR5Al and NEUROD1 were overexpressed in $82 \%$ of the cases.

To determine whether gene up-regulation translates into higher levels of the encoded protein, we obtained formalin-fixed, paraffin-embedded (FFPE) tissue blocks from 18 of the adenomas analyzed by qRT-PCR, and stained them for P450scc and NuSAP. Normal anterior pituitary cells had only weak cytoplasmic positivity for P450scc in sparse hypophyseal cells, while P450scc staining was more intense, although often uneven, in adenomas (Fig. 3b). Immunoreactivity score (IRS) were calculated and showed that 13 of 18 cases ( $72 \%$ ) had a IRS $\geq 6$, indicating moderate to strong staining in up to $75 \%$ of the tumor cells, and 5 cases $(28 \%)$ showed weaker staining (IRS $\leq 4)$ (Fig. 3c). Of the human gonadotropinomas used for IHC, 9 were invasive and 8 non-invasive. No significant difference in the degree of positivity for P450scc was observed between the two groups of tumors.

We also performed IHC to detect NuSAP expression and we could detect tumor cells having a strong, nuclear staining in every human PA sample (Fig. 3b). Being NuSAP associated with mitosis, we determined the relationship between its expression and that of the Ki67 antigen, an established marker of cell division. Quantification of the IHC results demonstrated that Ki-67-positive cells were more numerous than NuSAP-positive cells (Fig. 3c). NuSAP-positive pituitary tumor cells always co-expressed Ki-67 (Fig. 4a). Co-expression of the two markers was also seen in rat PAs, which have elevated proliferation rates (Fig. 4a) [26]. A good correlation between the Labeling Index (LI) of NuSAP and of Ki-67 was seen in the human tumor tissue samples $\left(R^{2}=0.8131\right)$ (Fig. $\left.4 \mathrm{~b}\right)$.

Cyp11a1 plays a pro-proliferative role in tumorigenesis

We have established that Cypllal is highly expressed in rat and human gonadotroph tumors at mRNA and protein levels. To clarify the role of this gene in tumorigenesis, we first used Y1 cancer cells derived from a steroidogenic 


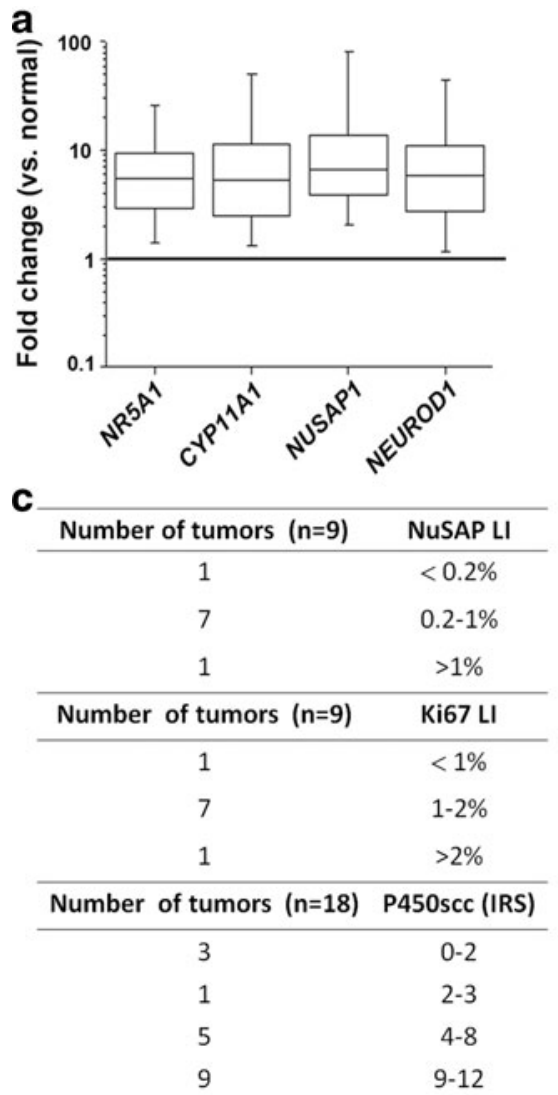

Fig. 3 Overexpression of CYP11A1 and NUSAP1 and their encoded proteins in human gonadotroph tumors. a RNA was extracted from frozen pituitary tumors obtained after transsphenoidal surgery. qRTPCR was performed using TaqMan primer and probe sets specific to human NR5A1, CYP11A1, NUSAP1 and NEUROD1. The relative mRNA expression level of the target genes was normalized for input RNA using human TBP gene expression (housekeeping gene) and a calibrator human brain RNA always run in parallel and was calculated with the $2^{-\Delta \Delta \mathrm{Ct}}$ formula. The obtained relative value was normalized against the average expression of normal pituitary arbitrarily

tissue and expressing Cypllal at high level. siRNA-mediated knock-down of Cypllal reduced the ability of Y1 cells to proliferate when compared with cells transfected with scrambled siRNA oligos (Supplementary Fig. 4b). Efficient knock-down of the Cypllal gene was verified by qRT-PCR (Supplementary Fig. 4a). Encouraged by these findings we pursued the role of Cypllal overexpression in pituitary tumorigenesis. We used somatotroph adenomaderived GH3 cells, which express relatively high levels of Cypllal (Supplementary Fig. 5), to evaluate the effect of modulating gene expression on pituitary tumor cell proliferation. We found that siRNA-mediated silencing of Cyp 1 lal reduced GH3 cells proliferation, while scrambled siRNA oligos elicited no effect (Supplementary Fig. 4c, d).

qRT-PCR showed that rat primary PA cells maintain the high Cypllal expression level observed in the tumor

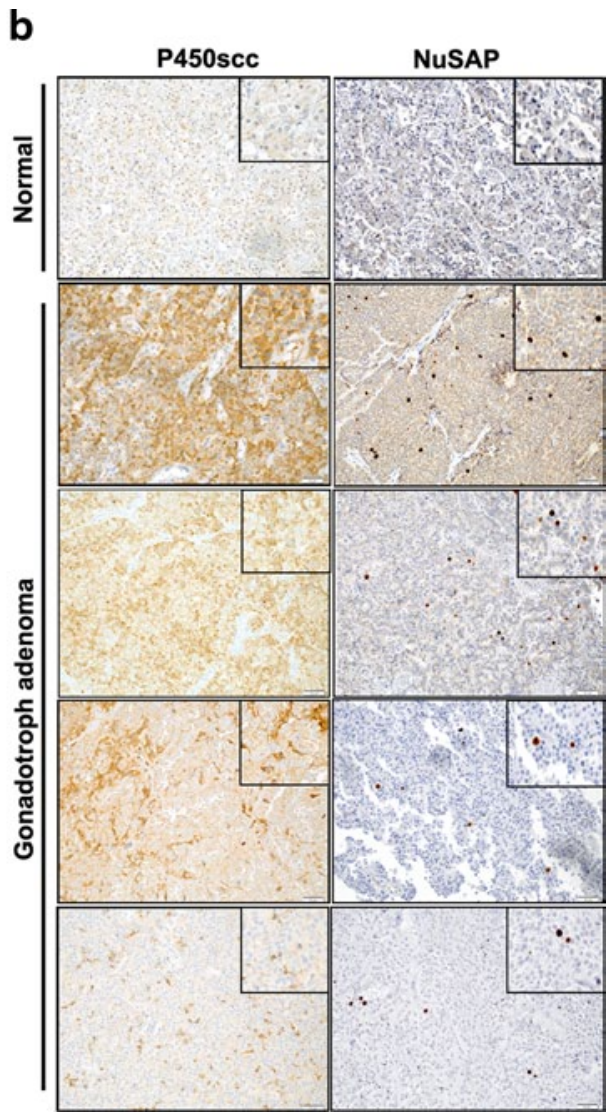

set to 1 . The boundary of the box closest to zero indicates the 25 th percentile, the line within the box marks the median, and the boundary of the box farthest from zero indicates the 75th percentile. Error bars above and below the box indicate the 99th and 1th percentiles. b Human normal pituitary (top) and gonadotroph adenoma samples were used. IHC was performed using antibodies against P450scc (left) or against NuSAP (right) and counterstained with hematoxylin. Original magnification: $\times 200$; insets: $\times 400$. c Scoring of the expression of NuSAP, Ki-67 and P450scc in a series of human gonadotroph adenomas

tissues from which they derive (Supplementary Fig. 5), and thus represent a suitable model for analyzing the effect of gene knock-down. As these cells were difficult to transfect, we generated a lentiviral vector expressing both a small hairpin (sh) RNA molecule directed against rat Cypllal and the green fluorescent protein (GFP) to monitor infection efficiency (ca. $80 \%$, data not shown). Two RNA sequences were tested but only one gave a consistent and robust gene down-regulation and was then used on further experiments (data not shown). The sh-Cypllal lentiviral vector was first tested in GH3 cells (Fig. 5a), where it caused a very strong decrease in Cypllal expression (Fig. 5b, c) and, concomitantly, a reduction in cell proliferation when compared with mock infected cells (GFP) (Fig. 5d). In growth curve experiments, viral-mediated Cypllal knock-down decreased the growth rate of GH3 
Fig. 4 Expression of Ki-67 and NuSAP in rat and human pituitary adenoma cells.

a Example of immunofluorescent staining with antibodies against Ki-67 (red) and NuSAP (green) performed on FFPE pituitary tumor tissues from a MENX rat (MENX) and from a patient with gonadotroph adenoma (Human). Nuclei were counterstained with DAPI. Only the tumor area is shown. Original magnification: $\times 100$. b Correlation between NuSAP and Ki-67 labeling index (LI) in 12 human gonadotroph adenoma samples

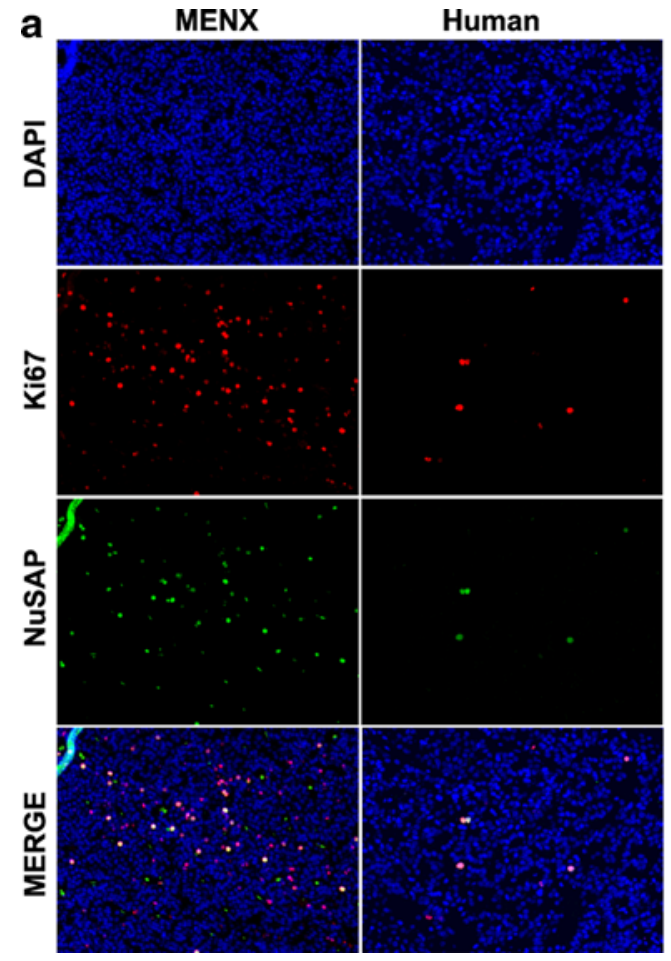

b

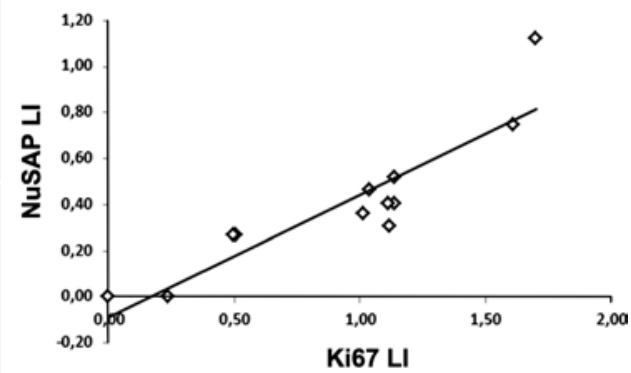

a

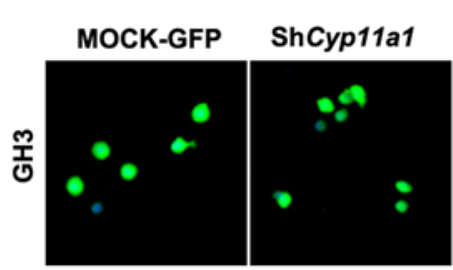

b

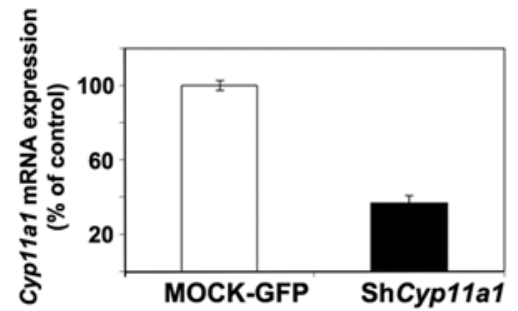

C

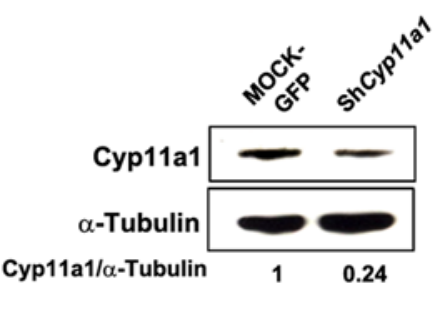

g

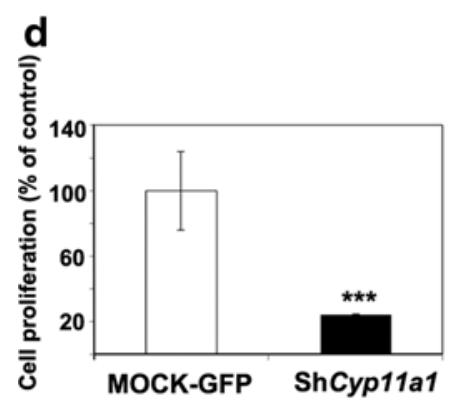

e

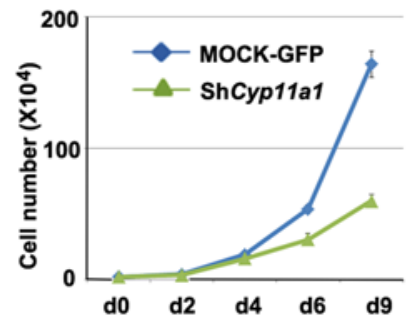

f

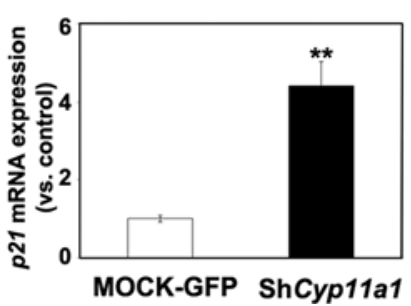

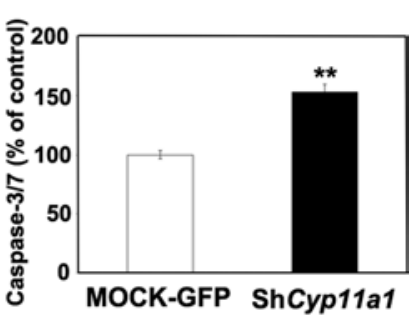

Fig. 5 Effect of Cypllal on tumor cell proliferation. a Infection of GH3 cells with lentiviral vectors expressing shCyp11a1-GFP or GFP only (MOCK). b GH3 cells were infected with the lentiviral vectors as in "a" and the level of Cypllal was analyzed by qRT-PCR $72 \mathrm{~h}$ later. c In samples parallel to "b", proteins were extracted, and Western blotting was performed to monitor Cyp11a1 expression. The ratios of the band intensities for P450scc versus $\alpha$-tubulin, normalized against the ratio in the MOCK control (ratio $=1$ ), is indicated. d In samples parallel to "b", cell proliferation was assessed $72 \mathrm{~h}$ after infection using the WST-1 assay. Data were analyzed independently with six replicates each and were expressed as the mean \pm SEM. e
Growth curve of GH3 cells infected with lentiviral vectors expressing shCyp11a1-GFP or GFP only (MOCK). Cells were trypsinized, stained with Trypan Blue and viable cells were counted. Values are the mean of 3 independent experiments \pm SD. $\mathbf{f}$ In samples parallel to "d", the expression of p21 was assessed by qRT-PCR as indicated in the legend of Fig. 1, and is reported relative to the expression level in mock-transfected cells arbitrarily set to 1 . $\mathbf{g}$ In samples parallel to "d", caspase 3/7 activity was measured to monitor apoptosis $72 \mathrm{~h}$ post-infection. Data were analyzed independently with six replicates each and were expressed as the mean \pm SEM. $* * P<0.01$, $* * * P<0.001$, versus MOCK 

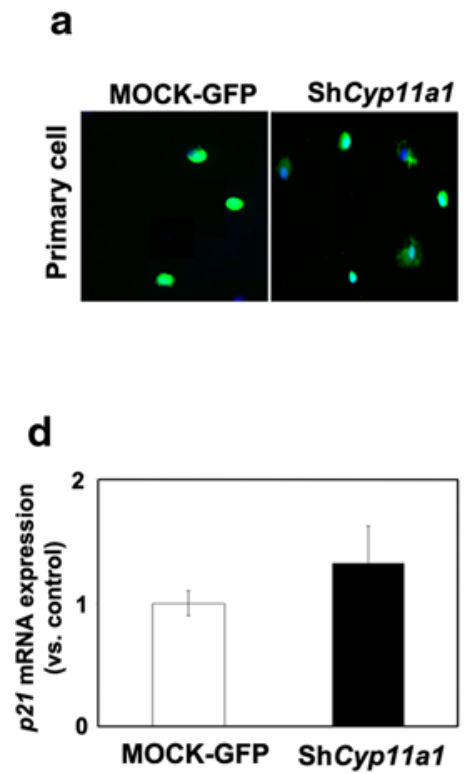
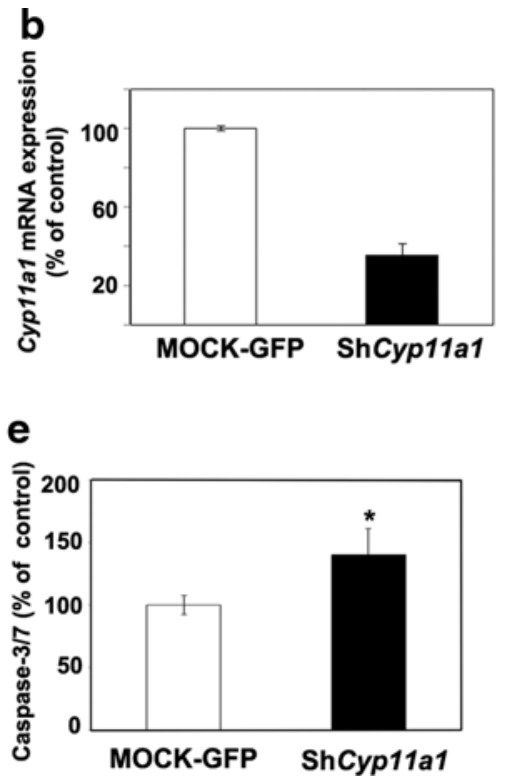

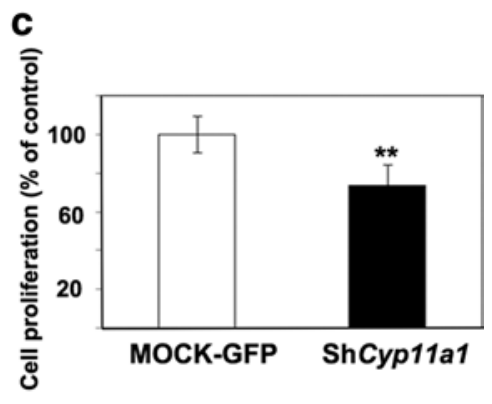

Fig. 6 Effect of Cypllal on primary pituitary tumor cell proliferation. a Infection of rat primary pituitary tumor cells with lentiviral vectors expressing shCyp11a1-GFP or GFP only (MOCK). b Primary pituitary tumor cells from three mutant rats were infected with the lentiviral vectors as in "a" and the level of Cypllal was analyzed by qRT-PCR as indicated in the legend of Fig. 1, and is reported relative to the expression level in mock-transfected cells arbitrarily set to 100 . c In samples parallel to "b", cell proliferation was assessed $72 \mathrm{~h}$ after infection using the WST-1 assay. Data were analyzed independently with six replicates each and were expressed as the mean \pm SEM. d In samples parallel to "c", the expression of p21 was assessed by qRT-PCR as indicated in the legend of Fig. 1, and is reported relative to the expression level in mock-transfected cells arbitrarily set to 1 . e Caspase $3 / 7$ activity was measured in samples in parallel to "c" to monitor apoptosis in GH3 cells $72 \mathrm{~h}$ post-infection. $* P<0.05$, $* * P<0.01$ versus MOCK cells, while infection with the mock vector had not effect on cell growth (Fig. 5e).

To determine what caused the reduction in the proliferation capacity of GH3 cells, we checked for the induction of cell cycle inhibitors following Cypllal gene knock-down. We determined the level of expression of p16, p18 and p21 after infection by qRT-PCR and we found that while the amount of p16 and p18 transcripts does not change (data not shown), p21 expression increases significantly upon reduction of Cypllal levels (Fig. 5f). We also assessed caspase-3/7 activity as a measure of apoptosis in GH3 cells infected with GFP or with sh-Cypllal. Caspase-3/7 activity is higher in cells infected by sh-Cypllal compared with mock infected cells, suggesting that this process might also explain part of the reduced cell growth (Fig. $5 \mathrm{~g}$ ). We then went back to our original model (MENX rats) and established primary PA cultures from three independent mutant rats. Cells were infected with sh-Cypllal vector, or with the mock GFP vector (Fig. 6a) and cell viability was measured. Upon infection of the primary cells with sh-Cypllal vector, but not with mock vector, we observed a reduction in Cypllal expression (Fig. 6b), which was accompanied by a decrease in cell viability $(-30 \%$ versus control GFP) (Fig. 6c). Similarly to what we observed in GH3 cells, also in primary rat PA cells there was an increase in both p21 expression and caspase-3/7 activity, although less pronounced than in GH3 cells (Fig. 6d, e). In conclusion, high expression of Cypllal associates with increased proliferation and survival not only in adrenocortical carcinoma cells (Y1), but also in rat pituitary tumor cells from different lineages (somatotroph and gonadotroph).

Rat PA cells express both Nr5al and Cypllal and, noteworthy, in these cells SF-1 and P450scc co-localize, as determined by dual co-immunofluorescence (Fig. 7a). SF-1 regulates Cypllal transcription in steroidogenic cells but whether it also does so in adenohypophyseal cells is not known. Therefore, we silenced Nr5al expression by means of siRNA oligos in gonadotroph L $\beta$ T2 cells and then assessed the level of Cypllal mRNA by qRT-PCR. As experimental control, we used again Y1 adrenocortical cancer cells, where $\mathrm{Nr} 5 \mathrm{al}$ gene down-regulation caused a reduction of Cypllal mRNA expression (Supplementary Fig. 6). We observed that knock-down of Nr5al in L $\beta$ T2 cells, as demonstrated by western blotting (Fig. 7b), associates with a decrease in Cypllal expression (Fig. 7c). To further confirm that SF-1 transcriptional activity plays a role in regulating Cypllal expression in these cells, we treated L $\beta$ T2 cells with a small molecule inhibitor of SF-1, isoquinolinone (IsoQ) [8]. This compound caused a significant dose-dependent reduction of Cypllal expression (Fig. 7d). Similar results were also obtained exposing rat primary PA cells (with high endogenous levels of 
a

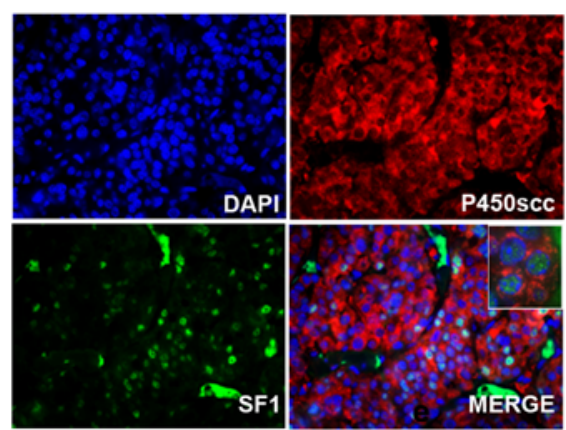

b

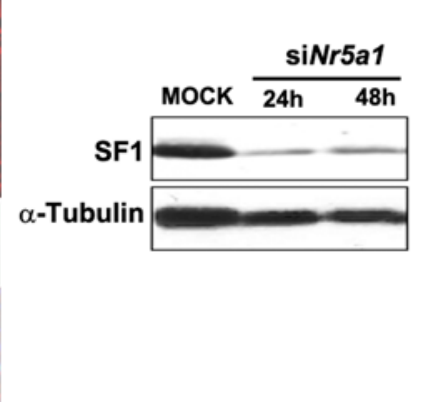

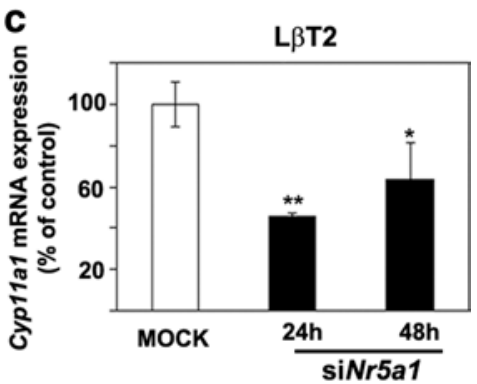

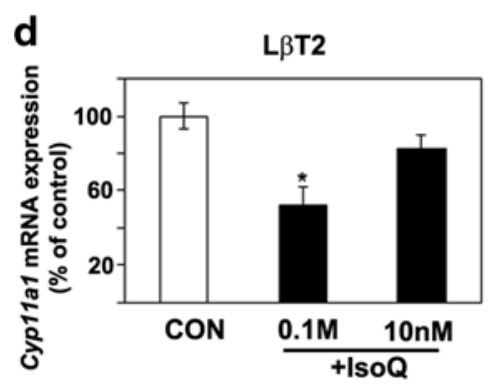

Fig. 7 Co-localization of P450scc and SF-1 in rat PAs and reduction of Cyp11al expression following down-regulation or inhibition of SF-1 in gonadotroph cells. a Immunofluorescent staining with antibodies against P450scc (red) and SF-1 (green) was performed on FFPE pituitary tumor tissues from MENX mutant rats. Nuclei were counterstained with DAPI. The inset in MERGE shows the colocalization of SF-1 and P450scc in rat tumor cells. Original magnification: $\times 200$; inset: $\times 400$. b L $\beta$ T2 cells were transfected with scrambled (MOCK) or siRNA oligos against the mouse $\mathrm{Nr} 5 \mathrm{al}$ gene (siNr5a1). SF-1 and $\alpha$-tubulin expression levels were assessed by Western blotting 24 and $48 \mathrm{~h}$ after transfection. c In samples parallel

Cyp11a1) to IsoQ (Fig. 7e). Altogether, these data provide indirect evidence that SF-1 is involved in regulating Cypllal expression in gonadotroph cells.

\section{Discussion}

We recently demonstrated that PAs developing in MENXaffected rats are pathologically similar to human gonadotroph adenomas [26]. The current study confirms this observation and shows that common genetic signatures exist between MENX-associated and human gonadotropinomas. In addition, novel putative markers of human PAs were identified, suggesting that MENX-associated neoplasms may be exploited as to gene discovery.

In silico analysis of gene expression array data of human gonadotroph adenomas identified several genes differentially expressed between tumors and normal pituitaries in both patients and MENX rats. An example of a gene downregulated in both rats and human PAs is Dlkl, encoding a non-canonical ligand of Notch. DLKI was found to be to "b", Cypllal expression level was assessed by qRT-PCR as indicated in the legend of Fig. 1, and is reported relative to the expression level in mock-transfected cells arbitrarily set to 100. d L $\beta$ T2 cells were treated with different concentrations of the SF-1 inhibitor IsoQ $(0.1 \mathrm{M}$ and $10 \mathrm{nM})$ or left untreated (CON). After $24 \mathrm{~h}$, we determined Cypllal expression levels as in "c". e Primary pituitary tumor cells from mutant rats $(n=3)$ were incubated with IsoQ as in "d". After 24 h, we assessed Cyp11al expression levels by qRT-PCR as in "c". Data from primary cultures were analyzed independently with six replicates each and were expressed as the mean \pm SEM. $* P<0.05, * * * P<0.001$ versus MOCK or CON

selectively silenced in NFPAs but not in other types of PA $[1,5] . D L K 1$ is located in the DLK1/MEG3 imprinted locus on human chromosome $14 \mathrm{q} 32.3$ and $M E G 3$, coding for a maternally imprinted long noncoding RNA with tumor suppressive function, was also found to be specifically silenced through methylation in NFPAs, but not in other hypophyseal adenoma types [13]. In rat PAs, Gtl2 (Meg3) is downregulated $(-1.95)$ but did not reach statistical significance.

Previous studies have compared human non-invasive and invasive/aggressive PAs with the aim to unveil the molecular mechanisms leading to an aggressive behavior and to identify markers predictive of invasiveness [12, 19, 43]. Some genes or gene families we found up-regulated in MENX adenomas had previously been identified in human aggressive-invasive PAs, e.g., PTTG1, RACGAP1, CCNB1, CENPE, AURKB [12]. PTTG1, the homologue of yeast securin, controls the faithful separation of sister chromatids [46], while deregulated expression of centrosome proteins (CENP) and Aurora kinases has been linked to defects in the mitotic machinery [41, 44]. Differential expression of the five genes mentioned above was observed 
among benign, pre-malignant and malignant tumors, with a tendency to higher expression in the more malignant ones, with Pttgl being expressed only in the latter group. Altogether, these findings further support our initial hypothesis that MENX-associated PAs resemble aggressive tumors [26], and suggest that these lesions may be exploited to identify novel targets for specific therapies of aggressive PAs, currently orphan of specific molecular-targeted treatment strategies. Moreover, our data further confirm the critical role of Pttgl in pituitary tumorigenesis across different species and genetic backgrounds.

NUSAP1 is among the genes overexpressed in both rat and human PAs but has not so far been investigated in these tumors. We here report that $90 \%$ of human gonadotroph adenomas express the NUSAPI gene at high level. Concordantly, the number of cells immunoreactive for NuSAP was higher in tumors compared with normal pituitaries. NuSAP is a microtubule-associated protein that bundles and stabilizes microtubules thereby linking chromosomes to the mitotic spindle [35]. Recently, overexpression of NUSAP1 has been found in various human cancers by array analysis, including glioblastomas, hepatocellular carcinomas, pancreatic adenocarcinoma (reviewed in [21]). The high expression of the NUSAPI gene has been associated with poor prognosis in melanoma patients [3], with a malignancy-risk genetic signature in breast cancer [4] and with recurrence in prostate cancer [15]. The study on prostate cancer has validated gene up-regulation seen by array analysis with immunostaining for the NuSAP protein: tumors with Gleason grading scores $\geq 7$ had more NuSAP-positive cells than tumors with lower scores [15]. We estimated the percentage of NuSAP-positive cells in human gonadotroph tumors (average $0.5 \%$, range $0.2-1 \%$ ) and found a correlation with that of $\mathrm{Ki}-67$-positive cells (average $1.2 \%$, range $0.5-2 \%$ ). Further studies are required to determine whether NuSAP labeling index correlates with the outcome of patients with PA and whether it provides a more accurate estimate of aggressive behavior than Ki67. Noteworthy, in addition to NUSAP1, our meta-analysis of human PA array data has identified the up-regulation of genes encoding other proteins playing a critical role in mitosis, mitotic spindle checkpoint and dynamics, or cytokinesis such as BUB1,CCNB1, CDC2, KIF4, $K I F 11, P R C 1$, in gonadotroph adenomas (Supplementary Table 2). These genes, if experimentally verified to be involved in PAs, may represent novel therapeutic targets for these tumors. While classical antimitotic compounds have limited clinical applications because of severe side effects, a new generation of drugs has been developed that targets kinesins (KIF proteins) and kinases with unique function in mitosis. These antitumor agents could be tested for the treatment of gonadotroph adenomas.
We observed that SF-1 and P450scc are co-expressed in PA cells of MENX-affected animals, and both siRNAmediated silencing of the Nr5al gene and treatment with the SF-1 inhibitor IsoQ resulted in the down-regulation of Cypllal in rat primary tumor cells and in L $\beta \mathrm{T} 2$ gonadotroph cells. These results indicate that SF-1 regulates Cypllal expression in gonadotroph cells. The transcriptional regulation of Cypllal in steroidogenic tissues is complex and involves the concerted action of several tissue-specific trans-regulators such as SF-1, DAX1, TReP132, LBP, and GATA together with transcription factors having a more widespread expression, including AP-1, Sp1, and AP-2 [16]. Further studies are needed to identify the additional factors involved in the transcriptional regulation of Cypl lal in PA cells.

CYP11A1 was up-regulated in $75 \%$ of human gonadotropinomas and $\mathrm{P} 450 \mathrm{scc}$ protein expression was high in these tumors, while barely detectable in normal pituitaries. P450scc has been detected in the developing mouse at embryonic day 9.5 in Rathke's pouch and at day 18.5 in the pituitary primordium [17]. However, its potential role in pituitary development or in the adult pituitary has not been addressed. Here we show that Cypllal plays a pro-proliferative role in $\mathrm{Y} 1$ adrenocortical cancer cells, but also in GH3 somatotroph adenoma cells and in rat primary pituitary gonadotroph cells. To the best of our knowledge, only two studies have so far addressed the putative role of Cypllal in regulating cell proliferation or viability. The first one showed that overexpression of CYP11A1 in tumorigenic and non-tumorigenic mammalian cell lines can either inhibit or enhance cell viability in a cell type-specific manner [7]. In cells sensitive to CYP11A1, gene overexpression led to decreased cell proliferation through increase of $\mathrm{p} 21$ expression and induction of apoptosis [7]. The authors did not investigate the molecular processes associated with CYP11A1-mediated increase in cell proliferation. Based on our results, when the reduction of CYP11Al level decreases cell proliferation (as seen in PA cells), both apoptosis and p21 expression are also involved, indicating that these are common pathways downstream of CYP11Al signaling. In a more recent study, a truncated isoform of P450scc was found to suppress osteoblast proliferation in physiological conditions [38]. Unlike the full length P450scc isoform, which is located in the mitochondria, this small isoform localizes to cytoplasm and nucleus, and might therefore be involved in still unidentified molecular pathways. Our studies show that Cypllal plays a pro-proliferative role in adrenocortical cancer and PA cells, thereby providing additional evidence supporting a role for this gene in tumorigenesis.

In conclusion, we here provide experimental evidence that the MENX animal model can be exploited as 
experimental tool to shed light into the pathomechanisms involved in human pituitary tumorigenesis. Several of the dysregulated genes here reported have never been associated with PAs, and may represent novel biomarkers for future clinical applications.

Acknowledgments We thank E. Samson, D. Mörzl and E. Pulz for excellent technical assistance, and Dr. P.L. Mellon for providing the L $\beta$ T2 cell line. This study was supported by grant SFB824 from the Deutsche Forschungsgemeinschaft (DFG) and grant \#107973 from the Deutsche Krebshilfe to N.S.P., and also in part by a research grant from Novartis Pharma GmbH, Nürnberg, Germany.

Open Access This article is distributed under the terms of the Creative Commons Attribution License which permits any use, distribution, and reproduction in any medium, provided the original author(s) and the source are credited.

\section{References}

1. Altenberger T, Bilban M, Auer M et al (2006) Identification of DLK1 variants in pituitary- and neuroendocrine tumors. Biochem Biophys Res Commun 340:995-1005. doi:10.1016/j.bbrc.2005. 12.094

2. Anastasov N, Klier M, Koch I et al (2009) Efficient shRNA delivery into B and $\mathrm{T}$ lymphoma cells using lentiviral vector-mediated transfer. J Hematopathol 2:9-19. doi:10.1007/s12308-008-0020-x

3. Bogunovic D, O'Neill DW, Belitskaya-Levy I et al (2009) Immune profile and mitotic index of metastatic melanoma lesions enhance clinical staging in predicting patient survival. Proc Natl Acad Sci USA 106:20429-20434. doi:10.1073/pnas.0905139106

4. Chen DT, Nasir A, Culhane A et al (2010) Proliferative genes dominate malignancy-risk gene signature in histologicallynormal breast tissue. Breast Cancer Res Treat 119:335-346. doi:10.1007/s10549-009-0344-y

5. Cheunsuchon P, Zhou Y, Zhang X et al (2011) Silencing of the imprinted DLK1-MEG3 locus in human clinically nonfunctioning pituitary adenomas. Am J Pathol 179:2120-2130. doi:10.1016/j.ajpath.2011.07.002

6. Davis SW, Castinetti F, Carvalho LR et al (2010) Molecular mechanisms of pituitary organogenesis: in search of novel regulatory genes. Mol Cell Endocrinol 323:4-19. doi:10.1016/ j.mce.2009.12.012

7. Derouet-Humbert E, Roemer K, Bureik M (2005) Adrenodoxin (Adx) and CYP11A1 (P450scc) induce apoptosis by the generation of reactive oxygen species in mitochondria. Biol Chem 386:453-461. doi:10.1515/BC.2005.054

8. Doghman M, Karpova T, Rodrigues GA et al (2007) Increased steroidogenic factor-1 dosage triggers adrenocortical cell proliferation and cancer. Mol Endocrinol 21:2968-2987. doi:10.1210/ me.2007-0120

9. Elston MS, Gill AJ, Conaglen JV et al (2008) Wnt pathway inhibitors are strongly down-regulated in pituitary tumors. Endocrinology 149:1235-1242. doi:10.1210/en.2007-0542

10. Ericson J, Norlin S, Jessell TM, Edlund T (1998) Integrated FGF and BMP signaling controls the progression of progenitor cell differentiation and the emergence of pattern in the embryonic anterior pituitary. Development 125:1005-1015

11. Evans CO, Young AN, Brown MR et al (2001) Novel patterns of gene expression in pituitary adenomas identified by complementary deoxyribonucleic acid microarrays and quantitative reverse transcription-polymerase chain reaction. J Clin Endocrinol Metab 86:3097-3107. doi:10.1210/jc.86.7.3097
12. Galland F, Lacroix L, Saulnier P et al (2010) Differential gene expression profiles of invasive and non-invasive non-functioning pituitary adenomas based on microarray analysis. Endocr Relat Cancer 17:361-371. doi:10.1677/ERC-10-0018

13. Gejman R, Batista DL, Zhong Y et al (2008) Selective loss of MEG3 expression and intergenic differentially methylated region hypermethylation in the MEG3/DLK1 locus in human clinically nonfunctioning pituitary adenomas. J Clin Endocrinol Metab 93:4119-4125. doi:10.1210/jc.2007-2633

14. Greenman Y, Stern N (2009) Non-functioning pituitary adenomas. Best Pract Res Clin Endocrinol Metab 23:625-638. doi:10.1016/j.beem.2009.05.005

15. Gulzar ZG, McKenney JK, Brooks JD (2013) Increased expression of NuSAP in recurrent prostate cancer is mediated by E2F1. Oncogene 32:70-77. doi:10.1038/onc.2012.27

16. Guo IC, Shih MC, Lan HC, Hsu NC, Hu MC, Chung BC (2007) Transcriptional regulation of human CYP11A1 in gonads and adrenals. J Biomed Sci 14:509-515. doi:10.1007/ s11373-007-9177-Z

17. Hammer F, Compagnone NA, Vigne JL, Bair SR, Mellon SH (2004) Transcriptional regulation of P450scc gene expression in the embryonic rodent nervous system. Endocrinology 145:901912. doi:10.1210/en.2003-0125

18. Hardy J (1979) The transsphenoidal surgical approach to the pituitary. Hosp Pract 14:81-89

19. Hussaini IM, Trotter C, Zhao Y et al (2007) Matrix metalloproteinase-9 is differentially expressed in nonfunctioning invasive and noninvasive pituitary adenomas and increases invasion in human pituitary adenoma cell line. Am J Pathol 170:356-365. doi :10.2353/ajpath.2007.060736

20. Ikuyama S, Mu YM, Ohe K et al (1998) Expression of an orphan nuclear receptor DAX-1 in human pituitary adenomas. Clin Endocrinol 48:647-654. doi:10.1046/j.1365-2265.1998.00477.x

21. Iyer J, Moghe S, Furukawa M, Tsai MY (2011) What's $\mathrm{Nu}(\mathrm{SAP})$ in mitosis and cancer? Cell Signal 23:991-998. doi:10.1016/j.cellsig.2010.11.006

22. Jiang Z, Gui S, Zhang Y (2012) Analysis of differential gene expression in plurihormonal pituitary adenomas using bead-based fiber-optic arrays. J Neurooncol 108:341-348. doi:10.1007/ s11060-011-0792-1

23. Kelberman D, Rizzoti K, Lovell-Badge R, Robinson IC, Dattani MT (2009) Genetic regulation of pituitary gland development in human and mouse. Endocr Rev 30:790-829. doi:10.1210 /er.2009-0008

24. Lee M, Theodoropoulou M, Graw J, Roncaroli F, Zatelli MC, Pellegata NS (2011) Levels of p27 sensitize to dual PI3 K/mTOR inhibition. Mol Cancer Ther 10:1450-1459. doi:10.1158/15357163.MCT-11-0188

25. Machiavelli GA, Rivolta CM, Artese R, Basso A, Burdman JA (1998) Expression of c-myc and c-fos and binding sites for estradiol and progesterone in human pituitary tumors. Neurol Res 20:709-712

26. Marinoni I, Lee M, Mountford S et al (2013) Characterization of MENX-associated pituitary tumours. Neuropathol Appl Neurobiol 39:256-269. doi:10.1111/j.1365-2990.2012.01278.x

27. Melmed S (2011) Pathogenesis of pituitary tumors. Nat Rev Endocrinol 7:257-266. doi:10.1038/nrendo.2011.40

28. Michaelis KA, Knox AJ, Xu M et al (2011) Identification of growth arrest and DNA-damage-inducible gene beta (GADD45beta) as a novel tumor suppressor in pituitary gonadotrope tumors. Endocrinology 152:3603-3613. doi:10.1210/en.2011-0109

29. Molatore S, Kiermaier E, Jung CB et al (2010) Characterization of a naturally-occurring p27 mutation predisposing to multiple endocrine tumors. Mol Cancer 9:116. doi:10.1186/1476-4598-9-116

30. Molatore S, Liyanarachchi S, Irmler M et al (2010) Pheochromocytoma in rats with multiple endocrine neoplasia (MENX) 
shares gene expression patterns with human pheochromocytoma. Proc Natl Acad Sci USA 107:18493-18498. doi:10.1073/p nas. 1003956107

31. Moreno CS, Evans CO, Zhan X, Okor M, Desiderio DM, Oyesiku NM (2005) Novel molecular signaling and classification of human clinically nonfunctional pituitary adenomas identified by gene expression profiling and proteomic analyses. Cancer Res 65:10214-10222. doi:10.1158/0008-5472.CAN-05-0884

32. Morris DG, Musat M, Czirjak S et al (2005) Differential gene expression in pituitary adenomas by oligonucleotide array analysis. Eur J Endocrinol/Eur Fed Endocr Soc 153:143-151. doi:10.1 530/eje.1.01937

33. Pellegata NS, Quintanilla-Martinez L, Siggelkow H et al (2006) Germ-line mutations in p27Kip1 cause a multiple endocrine neoplasia syndrome in rats and humans. Proc Natl Acad Sci USA 103:15558-15563. doi:10.1073/pnas.0603877103

34. Pereira AM, Biermasz NR (2012) Treatment of nonfunctioning pituitary adenomas: what were the contributions of the last 10 years? A critical view. Ann Endocrinol 73:111-116. doi:10.1016/j.ando.2012.04.002

35. Raemaekers T, Ribbeck K, Beaudouin J et al (2003) NuSAP, a novel microtubule-associated protein involved in mitotic spindle organization. J Cell Biol 162:1017-1029. doi:10.1083/ jcb.200302129

36. Rainer J, Sanchez-Cabo F, Stocker G, Sturn A, Trajanoski Z (2006) CARMAweb: comprehensive R- and bioconductor-based web service for microarray data analysis. Nucleic Acids Res 34:W498-W503. doi:10.1093/nar/gk1038

37. Scheithauer BW, Kovacs K, Zorludemir S, Lloyd RV, Erdogan S, Slezak J (2008) Immunoexpression of androgen receptor in the nontumorous pituitary and in adenomas. Endocr Pathol 19:2733. doi:10.1007/s12022-007-9012-0

38. Teplyuk NM, Zhang Y, Lou Y et al (2009) The osteogenic transcription factor runx 2 controls genes involved in sterol/steroid metabolism, including CYP11A1 in osteoblasts. Mol Endocrinol 23:849-861. doi:10.1210/me.2008-0270

39. Ueta Y, Levy A, Powell MP et al (1998) Neuronal nitric oxide synthase gene expression in human pituitary tumours: a possible association with somatotroph adenomas and growth hormonereleasing hormone gene expression. Clin Endocrinol 49:29-38. doi:10.1046/j.1365-2265.1998.00399.x

40. Val P, Martinez-Barbera JP, Swain A (2007) Adrenal development is initiated by Cited 2 and $\mathrm{Wt} 1$ through modulation of Sf- 1 dosage. Development 134:2349-2358. doi:10.1242/dev.004390

41. Vigneron S, Prieto S, Bernis C, Labbe JC, Castro A, Lorca T (2004) Kinetochore localization of spindle checkpoint proteins: who controls whom? Mol Biol Cell 15:4584-4596. doi:10.1091/mbc.E04-01-0051

42. Wang SM, Ooi LL, Hui KM (2011) Upregulation of Rac GTPase-activating protein 1 is significantly associated with the early recurrence of human hepatocellular carcinoma. Clin Cancer Res: Off J Am Assoc Cancer Res 17:6040-6051. doi:10.1158/1078-0432.CCR-11-0557

43. Wierinckx A, Auger C, Devauchelle P et al (2007) A diagnostic marker set for invasion, proliferation, and aggressiveness of prolactin pituitary tumors. Endocr Relat Cancer 14:887-900. doi:10.1 677/ERC-07-0062

44. Yao X, Abrieu A, Zheng Y, Sullivan KF, Cleveland DW (2000) CENP-E forms a link between attachment of spindle microtubules to kinetochores and the mitotic checkpoint. Nat Cell Biol 2:484-491. doi:10.1038/35019518

45. Zhan X, Desiderio DM (2010) Signaling pathway networks mined from human pituitary adenoma proteomics data. BMC Med Genomics 3:13. doi:10.1186/1755-8794-3-13

46. Zou H, McGarry TJ, Bernal T, Kirschner MW (1999) Identification of a vertebrate sister-chromatid separation inhibitor involved in transformation and tumorigenesis. Science 285:418-422. doi:10.1126/science.285.5426.418 